\title{
圧電材料のヒステリシスを表す一次元スイッチングモデル*
}

\author{
池田忠繁*1, 吉田圭吾*2, 上田哲彦*2
}

\section{One-Dimensional Switching Model for Hysteresis in Piezoelectric Materials}

\author{
Tadashige IKEDA ${ }^{* 3}$, Keigo YOSHIDA and Tetsuhiko UEDA \\ ${ }^{* 3}$ Department of Aerospace Engineering, Nagoya University, \\ Furo-cho, Chikusa-ku, Nagoya-shi, Aichi, 464-8603 Japan
}

\begin{abstract}
A simple yet accurate constitutive model for piezoelectric materials is proposed. The model is derived under the following two assumptions. ( $i$ ) Infinitesimal crystals in a piezoelectric material are considered, and the order of the energy required for the switching in a crystal is unchanged independently of the switching directions. (ii) The required switching energy is given in the form of a sum of two exponential functions of phase volume fraction. Comparison of electro-mechanical deformation behaviors between the calculation and the existing PLZT data verifies that this model can duplicate the hysteresis loops of the deformation behaviors among the stress, strain, electric field, and electric displacement. This indicates that the present model can provide a good tool to understand the mechanism of the deformation behavior of the piezoelectric materials and to design smart structures containing the piezoelectric elements.
\end{abstract}

Key Words: Constitutive Equation, Modeling, Smart Material, Smart Structure, Piezoelectric Materials, Hysteresis, Switching

\section{1.}

$\mathrm{PZT}\left(\mathrm{Pb}(\mathrm{Zr}, \mathrm{Ti}) \mathrm{O}_{3}\right)$ や PLZT (lanthanum doped PZT) に代表される生電材料は，それを構成している結晶が 自発分極を持ち，その結晶構造が中心対称でないため に，応力を加えるとその応力に比例した分極が生じ電 場が発生する．また逆に，電場を加えて分極させると 電場に比例した甭が生ずる.これらの現象を利用して 生電材料はセンサやアクチュエータとして用いること ができる. 小型軽量なので, 応力センサ, 加速度セン サ, 超音波トランスデューサ, 精密位置決めアクチュ エータなどとして広く利用されている。

この材料の挙動を表す構成方程式として，線形関係 式

$$
\begin{aligned}
& S_{i j}=s_{i j k l}^{E} T_{k l}+d_{i j n} E_{n}, \\
& D_{m}=d_{m k l} T_{k l}+\varepsilon_{m n}^{T} E_{n}
\end{aligned}
$$

\footnotetext{
* 原稿受付 2008 年 5 月 19 日.

*1 正員, 名古屋大学大学院工学研究科(雪 464-8603 名古屋市 千種区不老町)。

*2 名古屋大学大学院工学研究科.

E-mail : ikeda@nuae.nagoya-u.ac.jp
}

が用いられることが多く, 小さな応力や電場が加えら れたときは，その挙動を概ね表現することができる. ここで $S_{i j}, D_{m}, T_{k l}, E_{n}$ はそれぞれ奀, 電束密度, 応力, 電場を表し, $s_{i j k t}^{E}, d_{i j n}, \varepsilon_{m n}^{T}$ はそれぞれ電場 定での弾性コンプライアンス, 生電歪定数, 応力 定 での誘電率を表す。また，下付き添え字 $i, j, k, l$, $m, n$ は 1 から 3 の整数をとり, 座標軸を表す.

しかし, 大きな応力や電場が加えられると, 電場一 電束密度, 電場一硴, 応力一電束密度, 応力一奀のそ れぞれの間に非線形なヒステリシスが現れ，その挙動 を式(1)で表現することはできない，このヒステリシス はスイッチングと呼ばれる現象に伴うエネルギ損失が 原因であると考えられる，スイッチングとは，ある絶 対值以上の応力や電場が外部から加えられた際に結晶 の分極の向きが変わることであり，これにより奀や電 束密度に大きな変化が生ずる. 壮電材料をセンサやア クチュエータとして有効に用いるためには，その挙動 を止確に表現できる構成モデルが必要である.このた めいくつかのモデル(1)-(5)が提案されている.

このような状況の中で, 形状記憶合金の構成モデル の理論を用いて坐電材料の構成モデルを構築する研 究 $^{(6)}$, さらに, 壮電材料に代表される強誘電体 
(ferroelectric materials)，形状記憶合金に代表される 強弾性体 (ferroelastic materials), そして強磁性体 (ferromagnetic materials) まで含めた ferroic materials に ついて, 統 的な構成モデルを構築する吥究(7)が行わ れている.

方，簡単でかつ精度良く形状記憶合金の挙動を表 現できる構成モデルとして，Nae ら ${ }^{(8)}$, Ikeda ら ${ }^{(9),(10)} に$ より構築された構成モデルがある. Nae ら ${ }^{(8)}$ はモデル の構築にあたり，形状記憶合金をいくつかの種類の結 晶方向を持つ結晶粒の集まりとし，微小相変態中の工 ネルギ平衡より変態条件を, 平均操作と Reuss の伋定 を用いて奀の関係式を導出した. また，熱力学第二法 則より熱エネルギ変換方程式を導出し，奀速度の影響 も考慮した．次に Ikeda ら ${ }^{(9),(10)}$ は，この結晶粒レベル のモデルにおいて結晶粒の数を数学的に無限大にする ことにより, 試験片レベルの巨視的モデルを導出した. このモデルの特徴は，(1)各結晶粒の持つ相変態に対す るエネルギ障壁の大小の順は相変態前後の相に依らな いと仅定していることと, (2)相変態に対するエネルギ 障壁の大きさを二つの指数関数の和の形式で近似して いることである.このため取り扱いが容易になり，か つ, 試験片レベルの応力ー奀一温度関係についてヒス テリシスの形を精度良く表すことができる．今回，こ の形状記憶合余の構成モデルを恃電材料に適用するこ とにより，より良い土電材料の構成モデルを得ること ができると考えた.

以上の背景を踏まえ，本研究では Ikeda $5^{(9),(10)}$ の形 状記憶合金の構成モデルの理論を止電材料に適用し， 圷電材料の構成モデルを構築する，また， Lynch ${ }^{(1)} の$ PLZT に対する実験結果と比較することにより，その 妥当性を示す.

\section{2. 權成方程式}

本章では, Ikeda ら ${ }^{(9),(10)} の$ 形状記憶合金の構成モデル に基づき, 壮電材料の構成方程式を導出する. 本モデ ルでは形状記憶合金の表現にならつて, 結晶の分極方 向を「相」と呼ぶことで区別する. 今, 自発分極方向 に分極した結晶を $0^{\circ}$ 相，それに対して $180^{\circ}$ スイッチ ングした結晶を $180^{\circ}$ 相， $\alpha^{\circ}$ スイッチングした結晶を $\alpha^{\circ}$ 相と定義する. なお, 下付き添え字付き文字は総 和規約に従うテンソルとし, 下付き添え字 $i, j, k$ 等 は1から 3 の整数をとり, 座標軸の方向を表すものと する.

$2 \cdot 1$ 歪, 里束密度の网係式 歪 $S_{i j}$, 電束密度 $D_{m}$ はそれぞれ, 非線形なスイッチングによる歪 $S_{i j}^{S w}$, 電 束密度 $D_{m}^{S W}$, 応力による奀 $S_{i j}^{S T}$, 電束密度 $D_{m}^{S T}$, 電場
による泵 $S_{i j}^{E L}$ ，電束密度 $D_{m}^{E L}$ の和として，

$$
\begin{aligned}
& S_{i j}=S_{i j}^{S W}+S_{i j}^{S T}+S_{i j}^{E L}, \\
& D_{m}=D_{m}^{S W}+D_{m}^{S T}+D_{m}^{E L}
\end{aligned}
$$

と表すことができると仅定する.

応力による歪 $S_{i j}^{S T}$, 電束密度 $D_{m}^{S T}$, 電場による歪 $S_{i j}^{E L}$, 電束密度 $D_{m}^{E L}$ は, 式(1)より

$$
\begin{aligned}
& S_{i j}^{S T}=s_{i j k l}^{E} T_{k l}, \\
& D_{m}^{S T}=d_{m k l} T_{k l}, \\
& S_{i j}^{E L}=d_{i j n} E_{n}, \\
& D_{m}^{E L}=\varepsilon_{m n}^{T} E_{n}
\end{aligned}
$$

となる.ここで平均操作と Reuss の仮定を用いること により $s_{i j k l}^{E}, d_{m k l}, \varepsilon_{m n}^{T}, S_{i j}^{S W} ， D_{m}^{S W}$ はそれぞれ各相 の体積分率 $z^{\alpha}$ の関数として

$$
\begin{aligned}
& s_{i j k l}^{E}=z^{\alpha} s_{i j k l}^{E, \alpha}, \\
& d_{m k l}=z^{\alpha} d_{m k l}^{\alpha}, \\
& \varepsilon_{m n}^{T}=z^{\alpha} \varepsilon_{m n}^{T, \alpha}, \\
& S_{i j}^{S W}=z^{\alpha} S_{i j}^{\alpha}, \\
& D_{m}^{S W}=z^{\alpha} D_{m}^{\alpha}
\end{aligned}
$$

と書ける. 上付き添え字 $\alpha$ は $\alpha^{\circ}$ 相の值であることを 示す. $S_{i j}^{\alpha} ， D_{m}^{\alpha}$ はそれぞれ任意に与える基準状態から 計測した $\alpha^{\circ}$ 相の歪, 電束密度である，但し，上付き 添え字 $\alpha$ にいては総和をとる.

$2 \cdot 2$ スイッチング条件 $\quad \alpha^{\circ}$ 相から $\beta^{\circ}$ 相へスイ ッチングが生ずる場合のエネルギ平衡よりスイッチン グ条件を導出する. 図 1,2 にそれぞれ微小なスイッチ ング中の電場一電束密度線図, 応力一奀線図における エネルギ平衡の図的解积を示す．微小なスイッチング は定心力および 定電場の下で生ずるものとする.

電場一電束密度線図について微小なスイッチング 中のエネルギ平衡方程式は，図 1 にあるように（i ） 印加電場による仕事,（ii）散逸されるエネルギ,（iii） 誘電率の差によって蓄えられる静電エネルギ変化によ つて棈成され,

$$
E_{m} \frac{\partial D_{m}}{\partial z^{\beta}} d z^{\beta}=\Psi^{E-D} d z^{\beta}+\frac{1}{2} E_{m} \frac{\partial D_{m}^{E L}}{\partial z^{\beta}} d z^{\beta}
$$

と書くことができる.ここで $\Psi^{E-D}$ はスイッチング中 に結晶間の相百干渉によって散逸される単位体積分率 当たりのエネルギであり, 上付き添え字 $E-D$ は電場 一電束密度線図における值であることを示す。相間お よび結晶粒間の相互干涉がない場合, すなわち散逸が ない場合, 電場 $0[\mathrm{MV} / \mathrm{m}]$ でスイッチングが生ずる. 式 (5)に式(2.2)を代入すると 


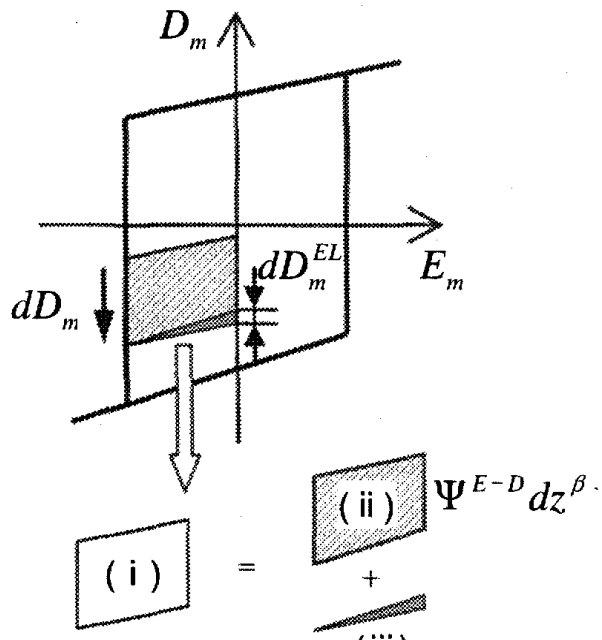

(iii)

Fig. 1 Geometric explanation of energy balance on electric field-electric displacement diagram.
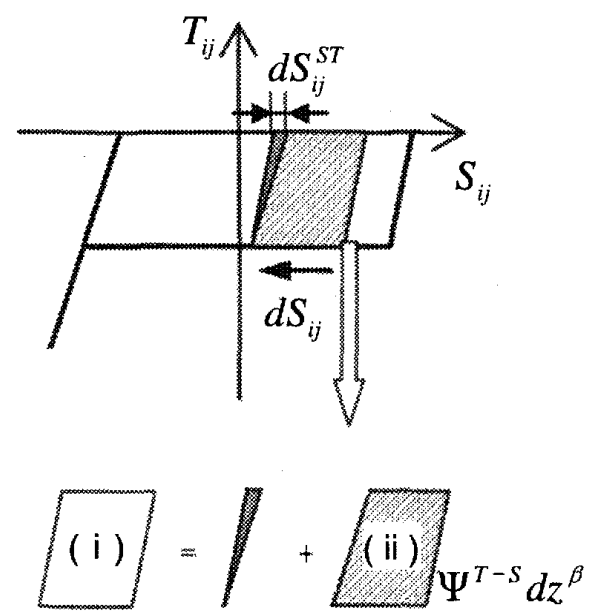

(iii)

Fig. 2 Geometric explanation of energy balance on stress-strain diagram.

$$
\begin{aligned}
& \frac{1}{2} E_{m} \frac{\partial D_{n i}^{E L}}{\partial z^{\beta}} d z^{\beta}+E_{m} \frac{\partial D_{m}^{S W}}{\partial z^{\beta}} d z^{\beta} \\
&+E_{m} \frac{\partial D_{n i}^{S T}}{\partial z^{\beta}} d z^{\beta}=\Psi^{E-D} d z^{\beta}
\end{aligned}
$$

となる.

同様に，応力一奀線図について微小なスイッチング 中のエネルギ平衡方程式は, 図 2 にあるように (i) 印加応力による仕事，（ii）散逸されるエネルギ，（iii） 弾性コンプライアンスの差によって蓄えられる弾性エ ネルギ変化によって構成され，

$$
T_{i j} \frac{\partial S_{i j}}{\partial z^{\beta}} d z^{\beta}=\Psi^{T-s} d z^{\beta}+\frac{1}{2} T_{i j} \frac{\partial S_{i j}^{S T}}{\partial z^{\beta}} d z^{\beta}
$$

と書くことができる. 但し, 上付き涯え字 $T-S$ は応 力ー奀線図における值であることを示す。また相間お よび結晶粒間の相灭干渉がない場合，すなわち散逸が ない場合, 応力 $0[\mathrm{MPa}]$ でスイッチングが生ずる. 式(7) に式(2.1)を代入すると

$$
\begin{array}{r}
\frac{1}{2} T_{i j} \frac{\partial S_{i j}^{S T}}{\partial z^{\beta}} d z^{\beta}+T_{i j} \frac{\partial S_{i j}^{S W}}{\partial z^{\beta}} d z^{\beta} \\
+T_{i i} \frac{\partial S_{i j}^{E L}}{\partial z^{\beta}} d z^{\beta}=\Psi^{T-S} d z^{\beta}
\end{array}
$$

となる.

式(6), (8)を足し合わせることにより応力, 電場双方 の影響を考慮したエネルギ平衡方程式として

$$
\begin{aligned}
& \frac{1}{2} E_{m} \frac{\partial D_{m}^{E L}}{\partial z^{\beta}} d z^{\beta}+E_{m} \frac{\partial D_{m}^{S W}}{\partial z^{\beta}} d z^{\beta} \\
& +E_{m} \frac{\partial D_{m}^{S T}}{\partial z^{\beta}} d z^{\beta}+\frac{1}{2} T_{i j} \frac{\partial S_{i j}^{S T}}{\partial z^{\beta}} d z^{\beta} \\
& +T_{i j} \frac{\partial S_{i j}^{S W}}{\partial z^{\beta}} d z^{\beta}+T_{i j} \frac{\partial S_{i j}^{E L}}{\partial z^{\beta}} d z^{\beta} \\
& =\Psi^{E-D} d z^{\beta}+\Psi^{T-S} d z^{\beta}
\end{aligned}
$$

を得る.ここで式(3.2)，(3.3)，(4.2)と $z^{\alpha}+z^{\beta}=1$ より

$$
\begin{aligned}
& \frac{\partial D_{m}^{S T}}{\partial z^{\beta}}=\left(d_{m k l}^{\beta}-d_{m k l}^{\alpha}\right) T_{k l}, \\
& \frac{\partial S_{i j}^{E L}}{\partial z^{\beta}}=\left(d_{i j n}^{\beta}-d_{i j n}^{\alpha}\right) E_{n}
\end{aligned}
$$

であり，また，相反則を考えれば，

$$
d_{m k k^{\prime}}=d_{k \mid m}
$$

であるので, 式(9)左辺の第 3 項と第 6 項は同じになる. これは電場一電束密度線図および応力ー奀線図につい てそれぞれ別々にエネルギ平衡を計算したために電気 機珹結合に関する項が重複してしまったためである. また散逸されるエネルギ $\Psi^{E-D}, \Psi^{T-S}$ も重複している.

従ってそれらを各々まとめ, 整理するとスイッチン グ条件は

$$
\Pi_{\alpha \rightarrow \beta}=\Psi_{\alpha \rightarrow \beta} .
$$

但し

$$
\begin{aligned}
& \Pi_{\alpha \rightarrow \beta}=\frac{1}{2} E_{m}\left(\varepsilon_{m m}^{T, \beta}-\varepsilon_{m n}^{T, \alpha}\right) E_{n} \\
& +E_{m}\left(D_{m}^{\beta}-D_{m}^{\alpha}\right)+E_{m l}\left(d_{m k l}^{\beta}-d_{m k l}^{\alpha}\right) T_{k l} \\
& +\frac{1}{2} T_{i j}\left(s_{i j k l}^{E, \beta}-s_{i j k l}^{E, \alpha}\right) T_{k l}+T_{i j}\left(S_{i j}^{\beta}-S_{i j}^{\alpha}\right)
\end{aligned}
$$

となる.ここでח $\Pi_{\alpha \rightarrow \beta}, \Psi_{\alpha \rightarrow \beta}$ はそれぞれ， $\alpha^{\circ}$ 相から $\beta^{\circ}$ 相へスイッチングするための熱力学的駆動エネル ギ, $\alpha^{\circ}$ 相から $\beta^{\circ}$ 相へのスイッチングに必要なエネル ギ (Required Switching Energy : RSE) を表し, 式(12) が满たされたときスイッチングが生ずることを示す。 
また，この RSEがエネルギ障壁に相当する.

\section{$2 \cdot 3$ 一次元スイッチングモデル このモデルで} は, 微小な結晶粒のRSEの大小の順番はスイッチング の種類によって不変であると伋定する. 図3では， $0^{\circ}$ 相, $90^{\circ}$ 相, $180^{\circ}$ 相の三相で構成された棒状の圷電材 料要素を考えている.ここで，微小な結晶粒は RSEの 小さい順に下から上へ向かって並べられている，棒要 素は，始め $0^{\circ}$ 相のみの状態にあり（図 3(a)），電場を $180^{\circ}$ 方向に加えていくと, まず $0^{\circ}$ 相から $90^{\circ}$ 相への スイッチングが下端から生じ（図 3 (b)），さらに電場 を強くしていくと, $0^{\circ}$ 相から $90^{\circ}$ 相へのスイッチング は上方へ進行し, $90^{\circ}$ 相から $180^{\circ}$ 相へのスイッチング が下端から生ずる (図 $3(\mathrm{c})$ ). 実際には, $0^{\circ}$ 相から $180^{\circ}$ 相へのスイッチングも生じるが，この例では生じてい ない. 次に電場を固定し, 生緶力を增加させていくと, $180^{\circ}$ 相から $90^{\circ}$ 相へのスイッチングが下端から生じ, 上方へ進行していく（図3(d)）。さらに生縮力を增加 させれば, $0^{\circ}$ 相から $90^{\circ}$ 相へのスイッチングも $0^{\circ}$ 相 の下端から生じ, 上方へ進行していき, 最終的には全 て90相の状態になる.

図3に示されるように，スイッチングは必ず下から 上へ 次元的に生ずるので, このモデルを 次元スイ ッチングモデルと名付ける．また，ある相の領域の長 さの和を棒要素全体の長さで無次元化した值は，その 相の体積分率に相当するので, 縦軸を体積分率座標 (Volume Fraction Coordinate :VFC) と呼び，0〜1で表 す.

この 次元スイッチングモデルを定式化すると,

$$
\Psi_{\alpha \rightarrow \beta}=\Psi_{\alpha \rightarrow \beta}\left(z_{1}^{\alpha}\right)
$$

となる. $\Psi_{\alpha \rightarrow \beta}$ は, 要素全体が $\alpha^{\circ}$ 相のみの状態から $\beta^{\circ}$ 相のみの状態へ完全にスイッチングする時の RSE を表す関数である. $z_{1}^{\alpha}$ は, 図 3 に示すような, $\alpha^{\circ}$ 相 における最小の VFC の值である.

\section{3. 数值解析および実験值との比较}

本章では，第 2 章で導出した構成モデルを用いて， 恃電材料についての数值解析を行い，またモデルの検 証のために Lynch ${ }^{(1)}$ の PLZT に対する実験データとの 比較を行う. Lynch の実験では, 軸の応力, 電場の みを加えており,ここではその応力を $T_{33}$, 電場を $E_{3}$ と し, その方向の奀 $S_{33}$, 電束密度 $D_{3}$ を調べることにす る.この場合テンソルの下付き涯え字は全て 3 であり, 簡略化のためそれらを省略し，また， $\alpha^{\circ}$ 相に関する 量を表す添え字は下付きとする.

$3 \cdot 1$ 材料定数 数值解析に用いる材料定数は以

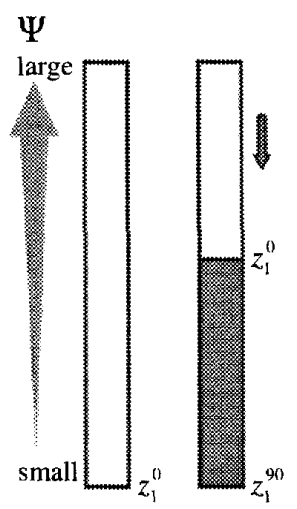

(a) (b)

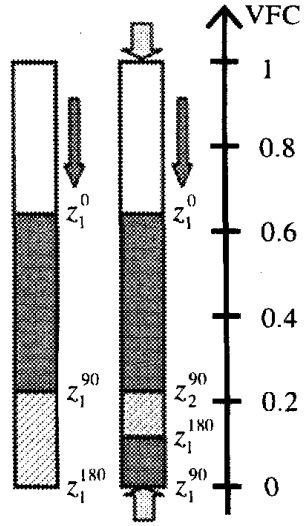

(d) electric field (c)
10 $0^{\circ}$-phase $90^{\circ}$-phase $Z 180^{\circ}$-phase of stress

Fig. 3 Concept of the one-dimensional switching model.

下のように決定する，まず，電場一電束密度線図（図 6 (a)の丸印) より, $0^{\circ}$ 相, $180^{\circ}$ 相の誘電率 $\varepsilon_{0}^{T}, \varepsilon_{180}^{T}$ お よ己゙固有電束密度 $D_{0}, D_{180}$ を。電場一奀線図（図7 (a) の丸印) より圷電奀定数 $d_{0}, d_{180}$ および固有泵 $S_{0}, S_{180}$ を，応力ー奀線図（図9の丸印）より弾性コンプライ アンス $s_{0}^{E}, s_{180}^{E}$ を推定する. $90^{\circ}$ 相の固有電束密度 $D_{90}$, 龶電奀定数 $d_{90}$, 誘電率 $\varepsilon_{90}^{T}$ は全て 0 とする. $90^{\circ}$ 相の 弾性.コンプライアンス $s_{90}^{E}$ および固有歪 $S_{90}$ は以下の 方法で決定する. PLZT の応力一電束密度線図（図 8 の丸印）より，応力を負荷し除荷した後もある 定の 電束密度が残っていることから, この応力負荷過程で は90スイッチングが完全に完了していないと考えら れる. 応力一電束密度線図（図 8 の丸印）上り除荷後 の $0^{\circ}$ 相および $90^{\circ}$ 相の体積分率が推定できるので, 応 カ一奀線図（図 9 の丸印）より得られる $90^{\circ}$ 相の弾性. コンプライアンス, 固有甭をもとに, $s_{90}^{E}, S_{90}$ を推定 することができる.

次に実験データより体積分率に対する RSE を推定 する．まず，各相の体積分率の時間変化を計算する. ここで実験デー夕は準静的であると仅定し，時間軸は 任意に決定した. 電場一電束密度線図 (図6 (a)の丸印) および電場一奀線図 (図7 (a)の丸印), 式(2)，(3)，(4), および全ての相の体積分率の和は 1 であることを考慮 することで, 電場を $0.8[\mathrm{MV} / \mathrm{m}]$ から $-0.8[\mathrm{MV} / \mathrm{m}]$ へ変化 させたときの各相の体積分率の時間変化として図 4 を 得る.ここで体積分率の值が $0 \sim 1$ 以外の值をとってい るのは，纴電セラミックスが $0^{\circ}$ 相， $90^{\circ}$ 相， $180^{\circ}$ 相 のみで構成されると伋定したためである.この図より， 電場が抗電場の約 $-0.4[\mathrm{MV} / \mathrm{m}]$ に達するまでは, $0^{\circ}$ 相 から $90^{\circ}$ 相へのスイッチングのみが，抗電場以降では $0^{\circ}$ 相から $180^{\circ}$ 相へのスイッチングと $90^{\circ}$ 相から $180^{\circ}$ 相へのスイッチングが生ずると考えられる. 以上 


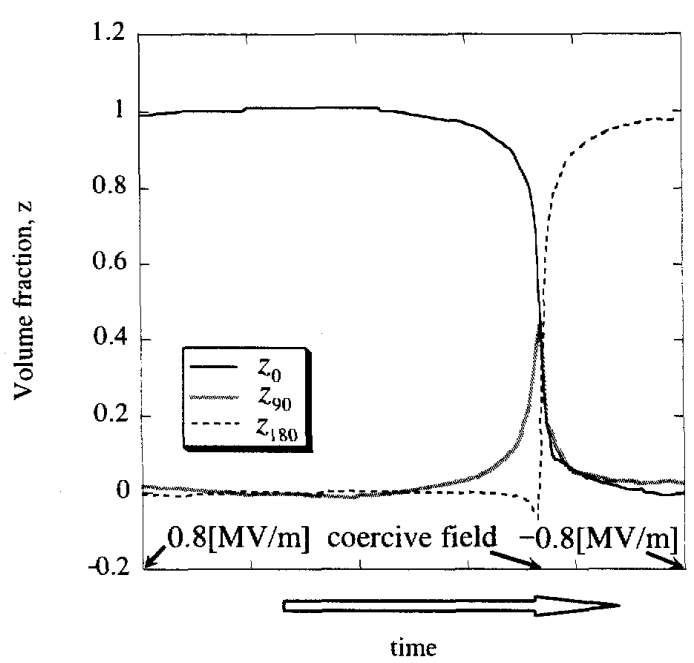

Fig. 4 Time variation of volume fractions.

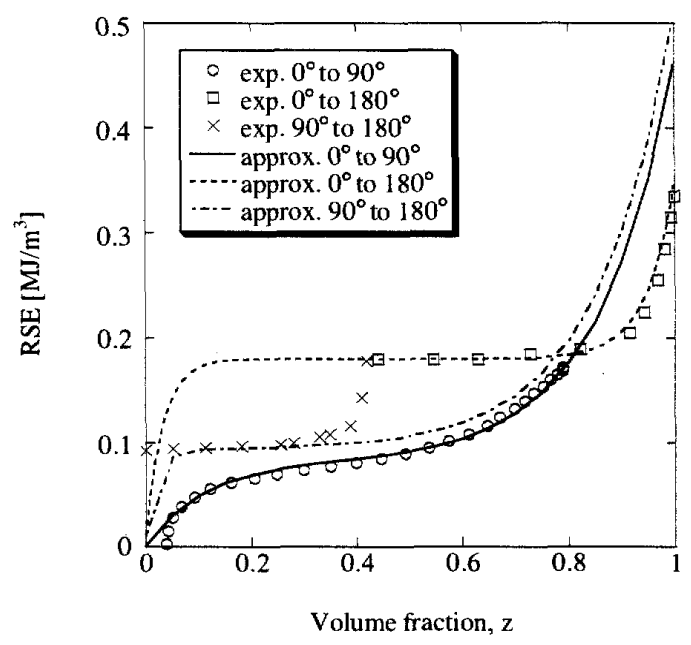

Fig. 5 Comparison of the approximation for required switching energy curves with the estimation from Lynch's experimental data ${ }^{(11)}$.

より，ある電場の值に対応する $0^{\circ}$ 相, $90^{\circ}$ 相, $180^{\circ}$ 相 の最小の VFC の値を得ることができ，また式(12)より 体積分率に対する RSE を推定することができる．００ 相から $90^{\circ}$ 相への RSEについては, より広範用の体積 分率に対する值を得るため，応力一電束密度線図（図 8 の丸印）と式(2.2)，(3.2)，(3.4)，(4.2)，(4.5)，(12)を 用いて推定する.

図5の丸印が実験データから推定した $0^{\circ}$ 相から $90^{\circ}$ 相への RSEである.ここで， RSE の值が体積分率 0.8 程度までしか得られていないのは, 今回用いた応力ー 電束密度線図（図 8 の丸印）において電束密度が 0 $\left[\mathrm{C} / \mathrm{m}^{2}\right]$ となっておらず， $0^{\circ}$ 相から $90^{\circ}$ 相へスイッチン グが完全には完了していないとしたためである.この グラフより, $0^{\circ}$ 相から $90^{\circ}$ 相への RSE は最小 VFC を
Table 1 Material constants.

\begin{tabular}{|c|c|c|c|}
\hline$s_{0}^{E}\left[\mathrm{~m}^{2} / \mathrm{N}\right]$ & $4.00 \times 10^{-11}$ & $\Psi_{\mathrm{cl}, 0 \rightarrow 40}\left[\mathrm{~J} / \mathrm{m}^{3}\right]$ & 0.00 \\
\hline$s_{90}^{E}\left[\mathrm{~m}^{2} / \mathrm{N}\right]$ & $9.64 \times 10^{-12}$ & $\Psi_{r 2,0 \rightarrow 90}\left[\mathrm{~J} / \mathrm{m}^{3}\right]$ & $8.00 \times 10^{4}$ \\
\hline$s_{180}^{E}\left[\mathrm{~m}^{2} / \mathrm{N}\right]$ & $4.00 \times 10^{-11}$ & $a_{1,0 \rightarrow \infty}$ & $10^{4}$ \\
\hline$d_{0}[\mathrm{~m} / \mathrm{V}]$ & $9.00 \times 10^{-10}$ & $a_{2,0 \rightarrow 90}$ & $10^{3}$ \\
\hline$d_{90}[\mathrm{~m} / \mathrm{V}]$ & 0.00 & $b_{0 \rightarrow 90}$ & 4.8 \\
\hline$d_{180}[\mathrm{~m} / \mathrm{V}]$ & $-9.00 \times 10^{-10}$ & $\Psi_{c, 0 \rightarrow 180}\left[\mathrm{~J} / \mathrm{m}^{3}\right]$ & $1.00 \times 10^{4}$ \\
\hline$\varepsilon_{0}^{T}[\mathrm{~F} / \mathrm{m}]$ & $3.54 \times 10^{-8}$ & $\Psi_{c 2,0 \rightarrow 180}\left[\mathrm{~J} / \mathrm{m}^{3}\right]$ & $1.70 \times 10^{5}$ \\
\hline$\varepsilon_{90}^{T}[\mathrm{~F} / \mathrm{m}]$ & 0.00 & $a_{1,0 \rightarrow 180}$ & $10^{13}$ \\
\hline$\varepsilon_{180}^{T}[\mathrm{~F} / \mathrm{m}]$ & $3.54 \times 10^{-8}$ & $a_{2,0 \rightarrow 180}$ & $10^{8}$ \\
\hline$S_{0}$ & 0.00146 & $b_{0 \rightarrow 180}$ & 1 \\
\hline$S_{90}$ & -0.00185 & $\Psi_{c 1,90 \rightarrow 180}\left[\mathrm{~J} / \mathrm{m}^{3}\right]$ & $1.00 \times 10^{4}$ \\
\hline$S_{180}$ & 0.00146 & $\Psi_{r 2,90 \rightarrow 180}\left[\mathrm{~J} / \mathrm{m}^{3}\right]$ & $8.30 \times 10^{4}$ \\
\hline$D_{0}\left[\mathrm{C} / \mathrm{m}^{2}\right]$ & 0.25 & $a_{1,90 \rightarrow 180}$ & $10^{20}$ \\
\hline$D_{90}\left[\mathrm{C} / \mathrm{m}^{2}\right]$ & 0.00 & $a_{2,90 \rightarrow 180}$ & $10^{3}$ \\
\hline$D_{180}\left[\mathrm{C} / \mathrm{m}^{2}\right]$ & -0.25 & $b_{90 \rightarrow 180}$ & 5 \\
\hline
\end{tabular}

変数とする $2 つ の$ 指数関数の和

$$
\begin{aligned}
\Psi_{\alpha \rightarrow \beta} & =\Psi_{\mathrm{c} 1, \alpha \rightarrow \beta}+\Psi_{c 2, \alpha \rightarrow \beta} \\
& \times\left\{1-a_{1, \alpha \rightarrow \beta}-z_{1}^{\alpha}+b_{\alpha \rightarrow \beta} a_{2, \alpha \rightarrow \beta}-\left(1-z_{1}^{\alpha}\right)\right\}
\end{aligned}
$$

によって近似する.ここで $-z_{1}^{\alpha},-\left(1-z_{1}^{\alpha}\right)$ は指数であ る. $\Psi_{t 1, \alpha \rightarrow \beta}, \Psi_{t 2, \alpha \rightarrow \beta}, a_{1, \alpha \rightarrow \beta}, a_{2, \alpha \rightarrow \beta}, \quad b_{\alpha \rightarrow \beta}$ はそ れぞれ定数であり,これらの值は試行錯誤により簡単 に概数実験データからの推定值と合うように選ぶこと ができる. $0^{\circ}$ 相から $90^{\circ}$ 相への RSE の体積分率が 0.8 程度以上の範网に関しては適当に推测し決定した。 図 5 の実線が $0^{\circ}$ 相から $90^{\circ}$ 相へのRSEの近似曲線である. 図より, 式(14)が RSE の特徽を定量的に捉えているこ とが分かる.

図 5 の四角印，バツ印がそれぞれ実験データから推 定した $0^{\circ}$ 相から $180^{\circ}$ 相, $90^{\circ}$ 相から $180^{\circ}$ 相への RSE である.ここで実験データから推定した $0^{\circ}$ 相から $180^{\circ}$ 相へのRSEの值が体積分率 0.4 程度以上でしが得 られていない，これは，抗電場以降でのみ $0^{\circ}$ 相から $180^{\circ}$ 相へのスイッチングが生ずるためである. また, 実験值から推定した $90^{\circ}$ 相から $180^{\circ}$ 相への RSE の値 が体積分率 0.4 程度までしか得られていないのは，応 力を負荷していない場合の電場一奀線図において $90^{\circ}$ 相は 4 割程度しか生じないためである. 実験データか ら推定できない範井の RSE の值は $0^{\circ}$ 相から $90^{\circ}$ 相へ の場合之同様に決定した. $0^{\circ}$ 相から $180^{\circ}$ 相, $90^{\circ}$ 相 から $180^{\circ}$ 相への RSE の全体の近似曲線は図 5 におい てそれぞれ破線，点鎖線で示す。これらの場合も近 似曲線が, 実験データから推定した RSE の特徵を定量 


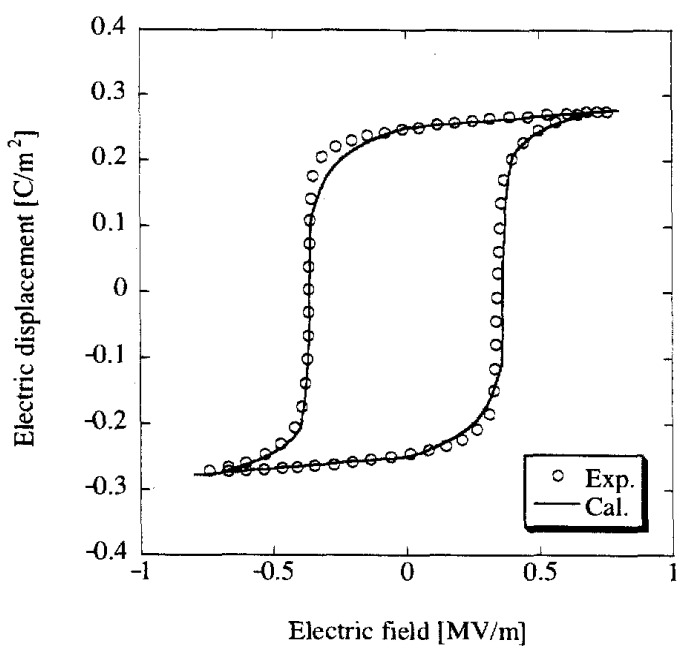

(a)

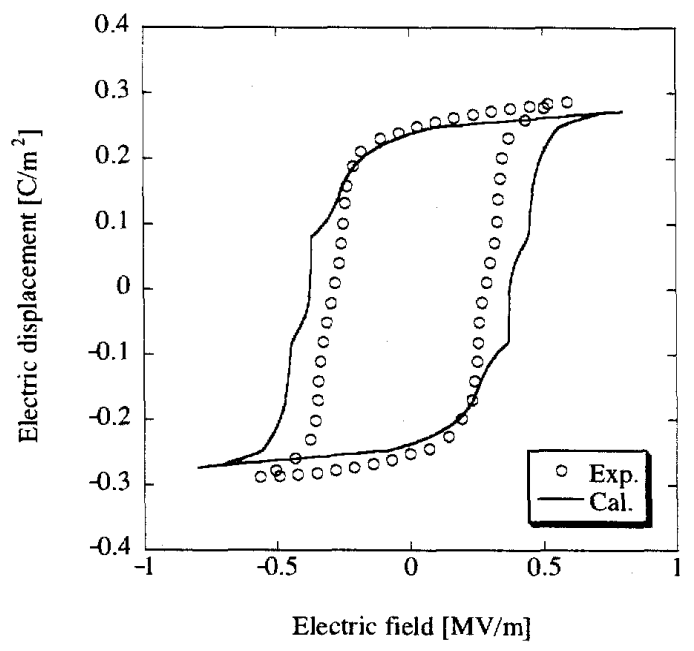

(c)

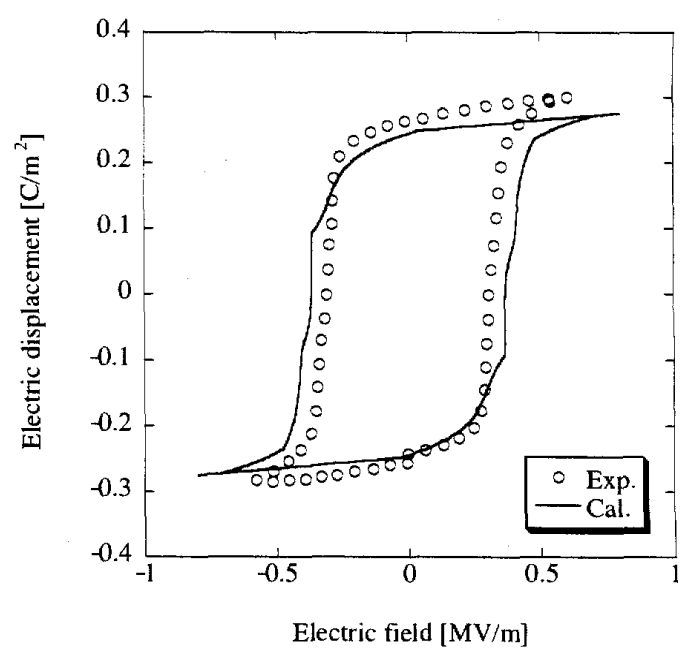

(b)

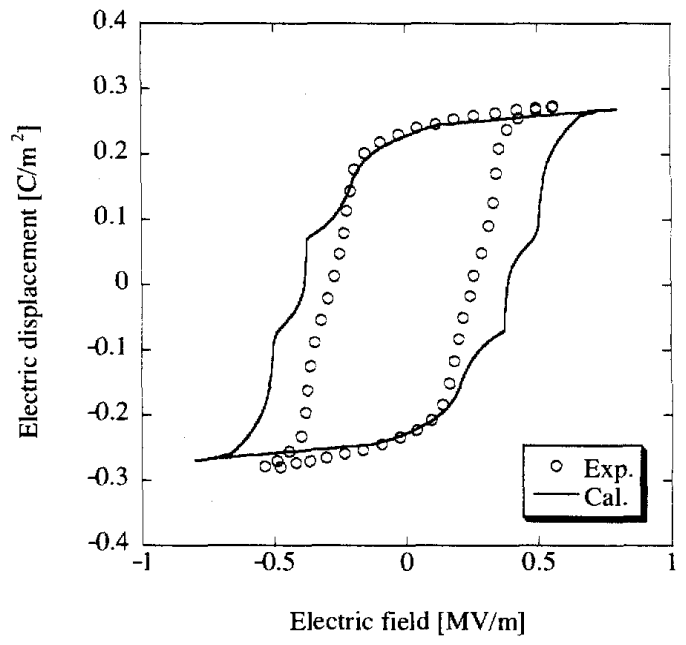

(d)

Fig. 6 Electric field-electric displacement curve under various applied stresses.

(a) $0 \mathrm{MPa}$, (b) -3MPa, (c) $-6 \mathrm{MPa}$, (d) $-10 \mathrm{MPa}$.

的に捉えていることがわかる.

なお今回 $0^{\circ}$ 相から $90^{\circ}$ 相へのスイッチングと $180^{\circ}$ 相から $90^{\circ}$ 相へのスイッチング， $0^{\circ}$ 相から $180^{\circ}$ 相へ のスイッチングと $180^{\circ}$ 相から $0^{\circ}$ 相へのスイッチング, $90^{\circ}$ 相から $180^{\circ}$ 相へのスイッチングと $90^{\circ}$ 相から $0^{\circ}$ 相へのスイッチングの RSE はそれぞれ等しいと伋定 した. 以上の方法を用いて得た材料定数を表 1 にまと める.

$3 \cdot 2$ 実鈋データとの比較 表1の材料定数を用 いた際の数值解析結果と Lynch ${ }^{(11)} の$ PLZT に対する実 験データとの比較を図6〜9に示す. 図6〜9はそれぞ れ，いくつかの生縮応力に対する電場一電束密度線図 および電場一歪線図, 電場 $0[\mathrm{MV} / \mathrm{m}]$ に打ける応力一電 束密度線図および応力ー奀線図である.ここで数值解 析結果は実線，実験データは丸印で表している.
電場一電束密度線図および電場一歪線図の実験デー 夕には以下のような特徵がある. 圷縮応力が 0 [MPa] のとき（図6 (a)，7 (a)），電場を $0.8[\mathrm{MV} / \mathrm{m}]$ から小さ くすると, 電束密度および甭はほぼ線形的に隇少して いく. 電場が $0[\mathrm{MV} / \mathrm{m}]$ に近づくと, $90^{\circ}$ 相へのスイッ チングが生じ, 電束密度および奀が大きく減少し始め る. 電場が約 $-0.4[\mathrm{MV} / \mathrm{m}]$ において $180^{\circ}$ 相へのスイッ チングが開始し, 電束密度はさらに大きく減少し, 歪 は急激に大きくなる，さらに電場を小さくすると, 電 束密度は $0.8[\mathrm{MV} / \mathrm{m}]$ の值と反対の符号の值に, 丕は 0.8 $[\mathrm{MV} / \mathrm{m}]$ の值と等しい值になる. 次にその状態から電場 を大きくすると，逆の現象が生じ，電束密度および甭 は元の值に戻る. 図からわかるように, 電場一電束密 度線図および電場一奀線図は電場の減少時と增加時に おいて同じ経路を通らず，大きなヒステリシスループ 


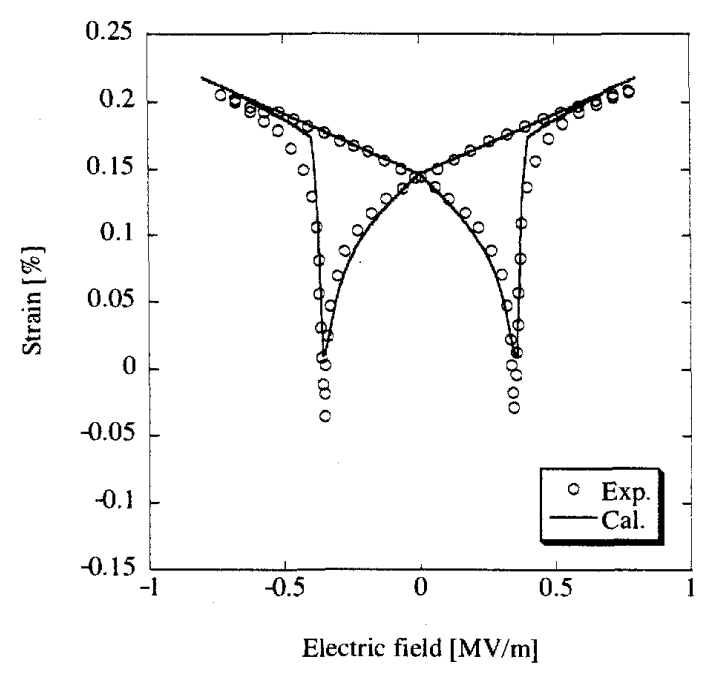

(a)

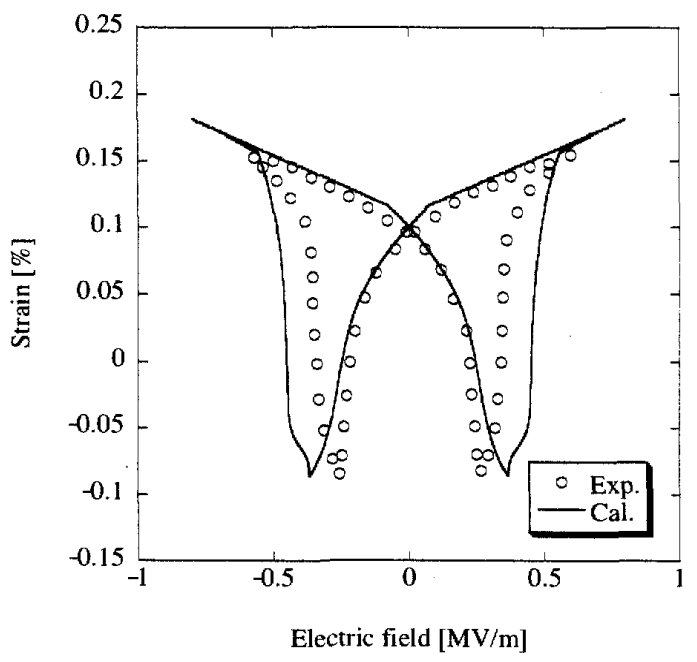

(c)

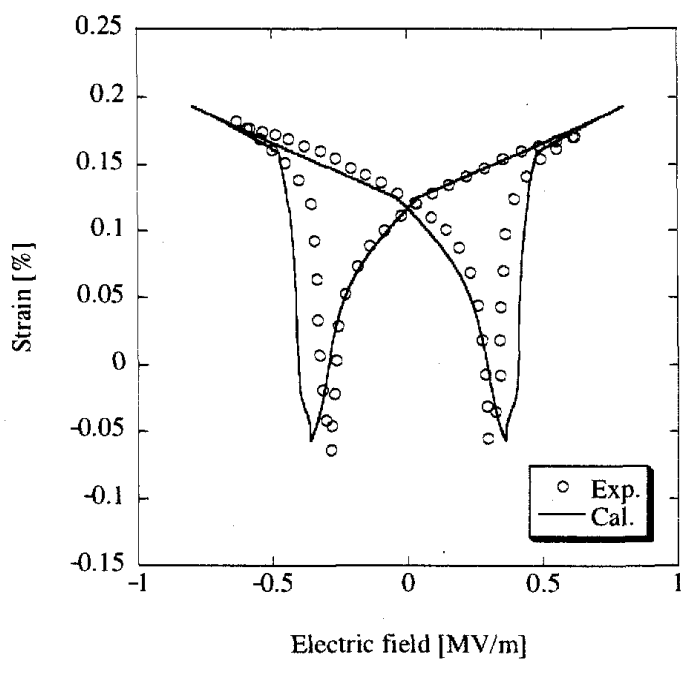

(b)

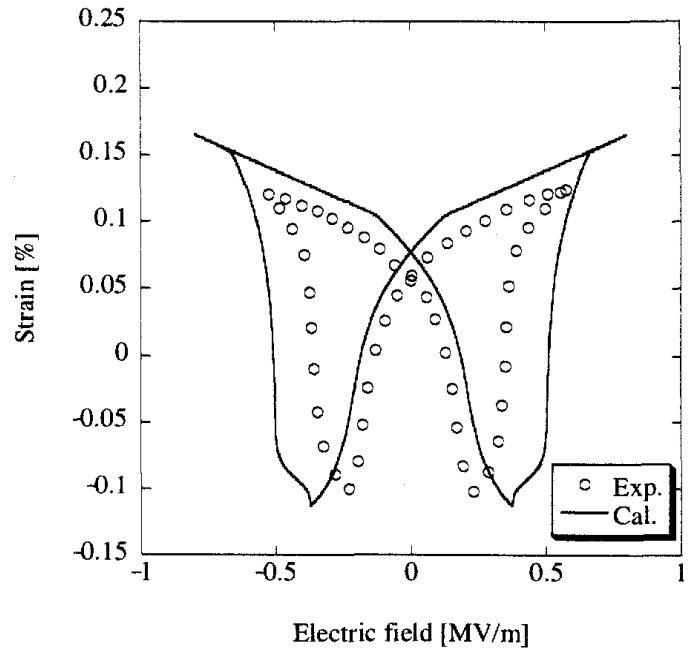

(d)

Fig. 7 Electric field-strain curve under various applied stresses. (a) $0 \mathrm{MPa}$, (b) $-3 \mathrm{MPa}$, (c) $-6 \mathrm{MPa}$, (d) $-10 \mathrm{MPa}$

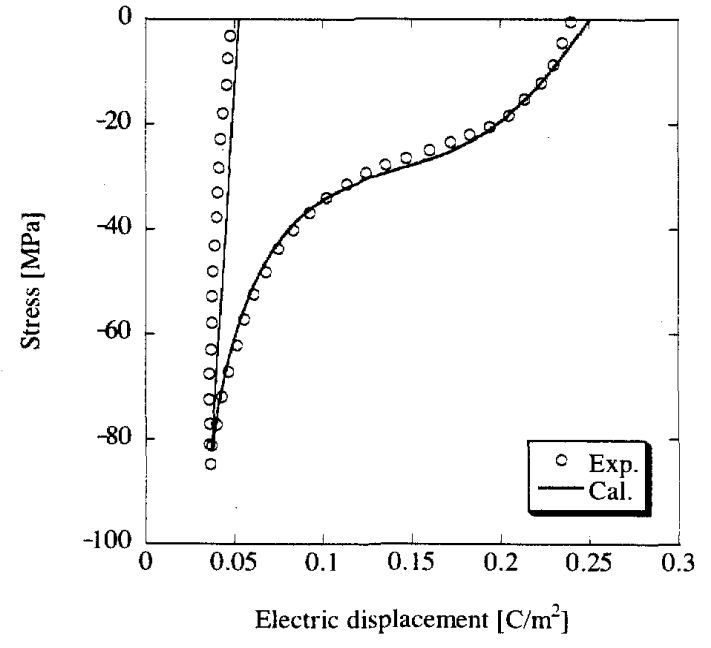

Fig. 8 Stress-electric displacement curve.

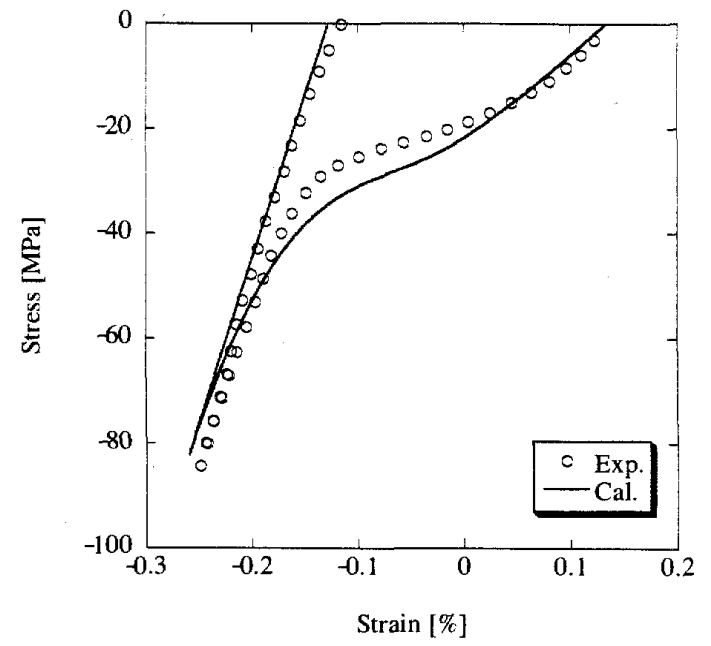

Fig. 9 Stress-strain curve. 
を描く.特に, 電場一甭線図はバ夕フライ形状になる. 此縮店力を大きくすると, 電場一電束密度線図は徐々 に止の傾きの方向へ傾いた形状をとるようになる（図 6 (b)〜(d)）. 方, 電場一奀線図は，バタフライ形ヒ ステリシス全体が奀の負の方向へ移動するとともに， バタフライ形状の「羽」の上部と下部が横に広がって w< (図 7 (b) (d)).

また，応力一電束密度線図およひ応力一奀線図の実 験データには以下のような特徵がある. 生維応力を 0 $[\mathrm{MPa}]$ から大きくすると, 電束密度は約 $0.25\left[\mathrm{c} / \mathrm{m}^{2}\right]$ から, 奀は約 $0.15[\%]$ からほほ線形的に減少していく，応力 が約-20 [MPa]に近づくと $90^{\circ}$ 相へのスイッチングが 開始し, 電束密度および奀は大きく減少する.その後, 除荷をしても，スイッチングは生じず，電束密度およ び奀は線形的に增加し，元の值には戻らない。

数值解析結果と実験データの比較より本モデルは, 生緶応力が $0[\mathrm{MPa}]$ ときは定量的に電場一電束密度 線図, 電場一奀線図のヒステリシスを捉え, 圷縮応力 が大きくなるに従い，実験デ一夕との差は多少大きく なるものの, 定性的にその変化の特徽を捉えているこ とがわかる.また，電場 $0[\mathrm{MV} / \mathrm{m}]$ における応力一電束 密度線図, 応力ー奀線図の七ステリシスも定量的に捉 えていることがわかる。

\section{4. 結}

簡単な形式で精度良く圷電材料の電気機械的変形特 性を表現することができる構成モデルを提案した。こ のモデルでは，(1)無限小の結晶粒を考え，結晶粒のス イッチングに必要なエネルギは，スイッチングの方向 に依らず不変であり，(2)必要エネルギは各極方向を向 いた結晶粒の体積分率に関する指数関数の和の形で表 されると敒定している．このモデルにより，既存の PLZT の電気機械的変形特性に関する実験デー夕を再 現した結果，材料定数の同定に用いた条件での変形特 性惊量的に捉えることができ，その他の条件でも， 多少の誤差はあるものの, パラメー夕変化に対する変 形特性の変化の様子を定性的には捉えることができた。
以上のことから，ここで提案したモデルは，簡単な形 式で精度が比較的良いので, 告電材料の電気機械的変 形挙動の理解や住電材料を含むスマート構造物の設計 に役に方つ道具になることが期待できる.

\section{文献}

(1) Chen, P. J. and Peercy, P. S., One Dimensional Dynamic Electromechanical Constitutive Relations of Ferroelectric Materials, Acta Mechanica, Vol. 31, No. 3-4 (1979), pp. 231-241.

(2) Chan, K. H. and Hagood, N. W., Modeling of Nonlinear Piezoceramics for Structural Actuation, Proceedings of the SPIE, Smart Structures and Materials 1994, Vol. 2190 (1994), pp. 194-205.

(3) Hwang, S. C., Lynch, C. S. and McMeeking, R. M., Ferroelectric/Ferroelastic Interactions and a Polarization Switching Model, Acta Metallurgica et Materialia, Vol. 43, No. 5 (1995), pp. 2073-2084.

(4) Kamlah, M. and Jiang, Q., A Constitutive Model for Ferroelectric PZT Ceramics under Uniaxial Loading, Smart Materials and Structures, Vol. 8 (1999), pp. 441-459.

(5) Li, W. F. and Weng, G. J., A Theory of Ferroelectric Hysteresis with a Superimposed Stress, Journal of Applied Physics, Vol. 91, No. 6 (2002), pp. 3806-3815.

(6) Smith, R. C., Seelecke, S., Ounaies, Z. and Smith, J., A Free Energy Model for Hysteresis in Ferroelectric Materials, Journal of Intelligent Material Systems and Structures, Vol. 14, No. 11 (2003), pp. 719-739.

(7) Smith, R. C., Seelecke, S., Dapino, M. J. and Ounaies, Z., A Unified Model for Hysteresis in Ferroic Materials, Proceedings of the SPIE, Smart Structures and Materials 2003, Vol. 5049 (2003), pp. 88-99.

(8) Nae, F. A., Matsuzaki, Y. and Ikeda, T., Micromechanical Modeling of Polycrystalline Shape-memory Alloys Including Thermo-mechanical Coupling, Smart Materials and Structures, Vol. 12 (2003), pp. 6-17.

(9) Ikeda, T., Nae, F. A., Naito, H. and Matsuzaki, Y., Constitutive Model of Shape Memory Alloys for Unidirectional Loading Considering Inner Hysteresis Loops, Smart Materials and Structures, Vol. 13 (2004), pp. 916-925.

(10) Ikeda, T., Modeling of Ferroelastic Behavior of Shape Memory Alloys, Proceedings of the SPIE, Smart Structures and Materials 2005, Vol. 5757 (2005), pp. 344-352.

(11) Lynch, C. S., The Effect of Uniaxial Stress on the Electro-mechanical Response of 8/65/35 PLZT, Acta Materialia, Vol. 44, No. 10 (1996), pp. 4137-4148. 